\title{
Protective effects of Gastrodia rhizoma and steamed \& fermented Gastrodiae rhizoma with anti-oxidant efficacy and suppression of NFKB signaling pathway on LPS-induced liver injury
}

\author{
Hyoung-Jin Kim ${ }^{1}$ O Jun Kwon ${ }^{2} \cdot$ Ah Reum Lee ${ }^{3} \cdot$ Seong-Soo Roh $^{3} \cdot$ Young-Bae Seo $^{1}$

\section{LPS로 유발한 간손상 마우스에서 항산화 및 항염증 효능을 통한 천마와 증숙 발효 천마의 간보호 효과}

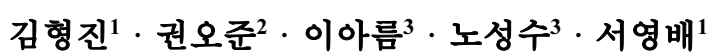

Received: 3 February 2016 / Accepted: 3 May 2016 / Published Online: 30 September 2016

(C) The Korean Society for Applied Biological Chemistry 2016

\begin{abstract}
This study is aimed to evaluate the protective effect of Gastrodiae rhizoma and steamed, dried \& fermented Gastrodiae rhizoma on Lipopolysaccharide (LPS)-induced hepatic injury in the mice model. Sample was selected to GR0F0 (not processed gastrodia rhizome) and GR6F4 (fermented with Saccharomyces cerevisiae before steamed and dried 6 times) based on 1,1diphenyl-2-picrylhydrazyl, 2,2'-azinobis-3-ethyl-benzothiazoline6-sulfonic acid, and High-performance liquid chromatography analysis. Mice were randomly divided into 4 groups - Normal group, vehicle group (LPS treated), GR0F0 group (fed GR0F0 before LPS treated) and GR6F4 group (fed GR6F4 before LPS treated) with 6 mice in each group. GR0F0 group and GR6F4 group were fed each extract $200 \mathrm{mg} / \mathrm{kg} /$ day during 8 days. LPS 20 $\mathrm{mg} / \mathrm{kg}$ injected to the experimental groups as abdominal injection.
\end{abstract}

Young-Bae Seo $(\bowtie)$

E-mail: genin@dju.ac.kr

${ }^{1}$ College of Korean Medicine, Daejeon University, 62 Daehak-ro, Dong-gu, Daejeon 34520, Republic of Korea

${ }^{2}$ Gyeongbuk Regional industry Evaluation, Daegyeong Institute for Regional Program Evalution, 27, Sampung-ro, Gyeongsan-si, Gyeongbuk 38542, Republic of Korea

${ }^{3}$ College of Korean Medicine, Daegu Haany University, 64 Gil, 25 Suseongro, Suseong-gu, Daegu 42158, Republic of Korea

This is an Open Access article distributed under the terms of the Creative Commons Attribution Non-Commercial License (http://creativecommons. org/licenses/by-nc/3.0/) which permits unrestricted non-commercial use, distribution, and reproduction in any medium, provided the original work is properly cited.
We measured aspartate aminotransferase, alanine amino-transferase in serum. GR0F0 and GR6F4 showed a significant decrease compared to the vehicle group. As a result of measuring the ROS, GR6F4 group showed a significant reduction in both the serum and liver tissues compared to the vehicle group. GR0F0 group showed a significant reduction only in the liver tissues. Activator protein-1, cyclooxygenase-2, and Inducible nitric oxide synthase were significantly decreased GR0F0 group and GR6F4 group. But tumor necrosis factor alpha only showed a significant reduction in GR6F4 group. GR0F0 and GR6F4 groups against liver damage in mice with LPS. That showed significant effects on anti-oxidant and anti-inflammatory action. The effects of GR6F4 group showed superior results compared to GR0F0 group. Therefore, Steamed, dried \& fermented Gastrodia rhizoma was might have a protective effect on liver injury.

Keywords Anti-inflammation · Anti-oxidation $\cdot$ Fermentation Gastrodiae rhizoma $\cdot$ Lipopolysaccharide $\cdot$ Liver injury

\section{서 론}

천마는 난초과(Orchidaceae)에 속한 다년생 기생본초인 Gastrodia elata $B$.의 덩이줄기를 쪄서 건조한 것이다( $\operatorname{Sin} 2008)$. 천마의 성분 중 gastrodin, gastrodigenin, ergothioneine 등이 유효성분 으로 알려져 있는데 gastrodin은 phenolic glycoside의 일종으로 천마의 주요 생리활성 물질이며 ergothioneine은 버섯의 주된 항 
산화 물질이다(Choi 등, 2011). 천마는 단단하여 절단하기가 어 려워 가공하는데 있어 예부터 다양한 방법이 사용되었으나 현 재는 증숙을 통하여 조직을 연화하는 방법과 효소를 이용하여 발효하는 방법이 가장 많이 사용되고 있다.

증숙한 천마는 품질유지에도 도움을 주는데, 천마를 건조할 경우 gastrodin 성분은 함량이 감소하고 gastrodigenin 성분의 함량은 증가하는 반면, 증숙 후 건조할 경우 gastrodin이 함량 이 증가하고 gastrodigenin의 함량이 극히 소량 존재하게 된다. 이것은 천마를 건조하면 가열로 인해 gastrodin의 분해효소가 불 활성화되어 gastrodin이 분해되지 않기 때문이다. Gastrodin의 aglycone인 gastrodigenin은 쉽게 산화되므로 천마는 가열처리를 해야 품질을 유지할 수 있다(Kim과 Song 2002).

발효는 아주 오래전부터 인류가 자연에서 발견한 인간에게 매우 유용한 가공기술로서 미생물의 작용을 통해 식품에 좋은 맛과 향, 조직감 등을 부여하고 유효성분을 증진시키는 작용을 한다. 이 가공기술은 장류, 요구르트, 술 등의 양조식품제조에 널리 사용되었으며(Song 등, 2011) 유효성분을 보다 작은 단위 로 분해하여 체내에 쉽게 흡수될 수 있게 함으로써 비위기능이 떨어지는 사람들에게도 적합한 제법으로 사용할 수 있다.

현재 발효천마에 대한 연구는 발효천마분말의 품질특성과 기 호도 조사(Kim 등, 2010), 발효천마 추출물의 성분 분석과 생 리활성 증강에 관한 연구(Choi, 2012), 천마와 발효천마의 특이 단백질 특성 연구(Ko 2010) 등 in vitro 실험이 대부분이고, in vivo 실험 연구로는 Streptozotocin으로 유도한 제1형 당뇨에서 의 항당뇨 효과(Kwon 2012), 유산균 발효 천마의 수면 유도 효과(Lee 등, 2013) 등으로 연구가 부족하다.

이에 본 연구자는 많이 사용되고 있는 증숙과 최근 들어 선 호되고 있는 가공방법인 발효의 가공과정을 거친 천마, 건조 천 마를 투여한 후 Lipopolysaccharide (LPS)에 의하여 간 손상이 유발된 mice 모델의 비교를 통해 항산화, 항염증작용을 살펴 본 바 유의성 있는 결과를 얻었기에 보고하는 바이다.

\section{재료 및 방법}

\section{실험재료}

실험에 사용된 천마(Gastrodiae Rhizoma)는 경북 김천시 부항면 대야리 일대에서 재배된 것으로, 2013년 12월에 수확된 생천마 중 上品만을 구입하여 시료제조에 사용하였다.

\section{시약}

미생물의 배양에 사용된 시약은 모두 Difco (Difco Laboratory, Detroit, MI, USA) 제품을 사용하였으며, 전처리에 사용된 효소 혼합액은 한국 화학연구원 융합화학연구팀에서 제공한 Cellulclast, HTec2, Amyloglucosidase 등의 1:1:1 혼합액을 사 용하였다.

Escherichia coli에서 얻어진 LPS (serotype O55:B5, L2880), 1,1-diphenyl-2-picrylhydrazyl (DPPH)와 2,2'-azinobis-3-ethylbenzothiazoline-6-sulfonic acid (ABTS)는 Sigma aldrich (St. Louise, MO, USA)에서 구입하였고, Nitrocellulose membranes 는 GE Healthcare (Arlington Heights, IL, USA)에서 구입하였 고, Phenylmethylsulfonyl fluoride (PMSF), nuclear factor- kappa B p65 (NF-кB p65), Inducible nitric oxide synthase (iNOS), cyclooxygenase-2 (COX-2), tumor necrosis factor alpha $(\mathrm{TNF}-\alpha)$, Histone, $\beta$-actin과 2차 항체는 Santa Cruz Biotechnology (Dallas, CA, USA)로부터 구입하였으며, Activator protein-1 (AP-1)은 Cell signaling technology (Danvers, MA, USA)에서 구입하였다. Dimethylsulfoxide, ethylenediaminetetraacetic acid (EDTA)는 Wako Pure Chemical Industries, Ltd. (Osaka, Japan)에서 구입하였다. 또한, 2',7'-Dichlorofluorescein diacetate (DCFH-DA)와 Dihydrorhodamine 123은 Molecular Probes (Eugene, OR, USA)에서 enhanced chemiluminescence (ECL) Western Blotting Detection Reagents는 GE Healthcare로부터 구입하여 사용하였다. 단백질 정량을 위한 $\mathrm{BCA}$ protein assay kit는 Thermo Scientific (Rockford, IL, USA)에서 구입하였다.

분석에 사용한 acetonitrile, ethanol 및 water는 High-performance liquid chromatography (HPLC) grade용으로 J.T.Baker (Center valley, PA, USA)로부터 구입하여 사용하였다. Phosphoric acid 와 formic acid는 Sigma-Aldrich로부터 구입하여 사용하였다.

\section{실험 동물}

생후 6주령의 체중 $25 \mathrm{~g}$ 내외의 ICR mice (Orient, Seongnam, Gyeonggi, Korea)를 구입하여 Light-dark cycle $12 \mathrm{~h}$, 온도 $25^{\circ} \mathrm{C}$, 습도 $60 \%$ 로 유지되는 조건 하에 일주일 동안 적응하여 사용하였다. 동물 사육실의 조건은 conventional system으로 온 도 $22 \pm 2^{\circ} \mathrm{C}$, 습도 $50 \pm 5 \%$, 명암주기(light-dark cycle)는 12시간 주기로 조절하였다. 사료는 고형사료(Samyang Corporation, Seoul, Korea) (조단백질 $22.1 \%$ 이상, 조지방 $8.0 \%$ 이하, 조섬 유 $5.0 \%$ 이하, 조회분 $8.0 \%$ 이하, 칼슘 $0.6 \%$ 이상, 인 $0.4 \%$ 이상, 삼양사(Seoul, Korea), 항생제 무첨가)와 물을 충분히 공 급하였다.

모든 실험은 대구한의대학교 동물실험 윤리위원회의 승인 (DHU2013-054)을 얻어 시행하였으며 동물관리 규정을 준수하 였다.

\section{시료제조}

시료 제조에 사용된 천마는 천마(GR0)와 증숙 천마로 구분 하 였고, 증숙 천마는 1증(GR1), 3증(GR3), 6증(GR6), 9증(GR9) 천마까지 제조하였다.

천마는 세척 후 일정 크기로 절단하여 건조기에서 건조하였 고, 증숙 천마는 1증부터 9증까지 일정한 시간동안 증숙하였고, 증숙 후 건조하여 증숙 횟수를 반복하였다. 증숙은 무압식 스 팀증숙기를 사용하여 증숙온도 $90^{\circ} \mathrm{C}$ 에서 2 시간씩 물로 증숙하 였고, 건조는 밀폐제습식 건조기를 사용하여 수분함량 $15 \%$ 미 만으로 4시간 동안 건조하였다. 천마의 발효에 사용된 균주는 Lactobacillus plantarum (F1), Leuconostoc mesenteroides (F2), Streptococcus thermophilus (F3), Saccharomyces cerevisiae (F4)로 대전대학교 미생명생물공학과 이찬용 교수로부터 받아 사용하였다. 발효 천마의 항산화 활성 및 성분 분석을 위한 시 료는 액상발효를 시행하였다. 사각 투명 밀폐용기에 각각 라벨 을 붙이고, 시료를 각각 $5 \mathrm{~g}$ 씩 넣은 후, $45 \mathrm{~mL}$ 의 멸균 증류수 를 첨가하여 현탁하였다 $(10 \% \mathrm{w} / \mathrm{v})$. 시료가 포함된 용기마다 미 리 혼합된 복합효소액 $0.5 \mathrm{~mL}$ 를 첨가하고 24 시간 반응시켰다. 시료에 따라 정해진 균주 현탁액을 $0.5 \mathrm{~mL}$ 씩 접종하여 섭씨 
$35^{\circ} \mathrm{C}$ 인큐베이터에서 정치 배양하였다. 접종시 균주의 농도는 생육에 따라 가감하여 $10^{7}-10^{8}$ cells $/ \mathrm{mL}$ 정도로 하였다. 샘플에 따라 간헐적으로 흔들어 주었다. 이후 매일 같은 시간에 발효 상태 $(\mathrm{pH})$ 를 확인하고 발효의 지속여부를 결정하였다.

동물 실험에 사용된 시료는 고형 발효를 시행하였다. 사각 투 명 밀폐용기에 각각 라벨을 붙이고, 시료를 샘플 하나당 2 개 씩 각각 $50 \mathrm{~g}$ 씩 총 $100 \mathrm{~g}$ 을 계량하여 넣었다. 여기에 $200 \mathrm{~mL}$ 의 멸 균 증류수를 첨가하여 현탁하였으며 $(20 \% \mathrm{w} / \mathrm{v})$ 시료가 포함된 용기마다 미리 혼합된 복합효소액 $2 \mathrm{~mL}$ 를 첨가하고 24시간 반 응시켰다. 시료에 따라 정해진 균주 현탁액을 $2 \mathrm{~mL}$ 씩 접종하여 섭씨 $35^{\circ} \mathrm{C}$ 인큐베이터에서 정치 배양하였다. 배양액을 $10^{7}-10^{8}$ cells $/ \mathrm{mL}$ 의 균주 농도를 맞추어 접종하였다. 샘플에 따라 간헐 적으로 흔들어 주었으며 매일 같은 시간에 발효상태 $(\mathrm{pH})$ 를 확 인하고 $35^{\circ} \mathrm{C}$ 로, 6 일간 발효하였다. 그 다음 발효한 시료를 동 결건조하였다. 동결건조는 $-30^{\circ} \mathrm{C}$ 에서 120 분, $-15^{\circ} \mathrm{C}$ 에서 120 분, $0^{\circ} \mathrm{C}$ 에서 240 분, $15^{\circ} \mathrm{C}$ 에서 120 분, $30^{\circ} \mathrm{C}$ 에서 120 분의 조건으로 시행하였다.

\section{DPPH radical scavenging activity 측정}

전자공여능(electron donating ability)은 DPPH radical 소거법으 로 측정하였다. DPPH는 프리라디칼(free radical)이며, 용액은 짙은 보라색(deep violet)으로 시료 중에 있는 항산화 물질과 결 합하여 중화(환원)가 되면 용액은 투명하게 변하므로 시료 중에 포함된 항산화(radical 소거능) 물질의 양을 측정하는데 사용된다. 일정 농도의 시료 $100 \mu \mathrm{L}$ 와 $60 \mu \mathrm{M} \mathrm{DPPH}$ 용액(dissolved in ethanol) $100 \mu \mathrm{L}$ 를 넣고 혼합한 후, 실온에서 30 분간 반응시켰 다. 이 반응액을 사용하여 $540 \mathrm{~nm}$ 에서 흡광도를 측정한 후, $\mathrm{DPPH}$ radical 소거능을 계산하여 산출하였다.

\section{ABTS radical scavenging activity 측정}

$7 \mathrm{mM}$ ABTS와 $2.45 \mathrm{mM}$ Potassium persulfate를 증류수에 녹 인 다음 12 시간 동안 차광하여 보관 한 후, 이 반응액을 415 $\mathrm{nm}$ 에서 ethanol을 이용하여 흡광도 $0.70 \pm 0.02$ 로 보정한다. 그 후, $\mathrm{ABTS} 95 \mu \mathrm{L}$ 에 시료 $5 \mu \mathrm{L}$ 을 첨가하여 15 분 반응 후, 415 $\mathrm{nm}$ 에서 흡광도를 측정하여 $\mathrm{ABTS}$ 라디칼 소거능을 계산하여 산출하였다.

\footnotetext{
성분분석

HPLC 분석에 사용한 이동상은 A: water $(0.2 \%$ phosphoric acid)와 B: aceto-nitrile $(0.2 \%$ phosphoric acid $)$ 을 gradient로 사용하여 용매기울기로 유속 $1.0 \mathrm{~mL} / \mathrm{min}$ 에서 column 온도 40 를 유지하면서 검출기는 UV $(225 \mathrm{~nm})$ 를 사용하였고 주입량은 $1 \mathrm{~mL}$ 를 주입하였다.

천마 및 발효 천마 시료액의 $1 \mathrm{~mL}$ 에 함유된 성분을 분석하 여 함량을 표로 나타내었다. 발효 천마는 gastrodin, gastrodigenin 의 함량을 분석하여 나타내었다.

천마의 분석에 사용한 표준품은 식품의약품안전청의 한약재 과학화연구사업단 이화여자대학교 서은경 교수로부터 천마에서 분리한 gastrodin, gastrodigenin 2종을 제공받아 사용하였다.
}

\section{LPS에 의한 급성 간손상 개선 효능평가}

ICR mice (6주령, 수컷)로부터 아무런 처치를 하지 않은 정상
군, LPS를 처치한 대조군, GR0F0 $200 \mathrm{mg} / \mathrm{kg}$ 의 용량을 1 일 1 회, 8일간 경구 투여한 $\mathrm{GR} 0 \mathrm{~F} 0$ 투여군, 그리고 $\mathrm{GR} 6 \mathrm{~F} 4200 \mathrm{mg} /$ $\mathrm{kg}$ 의 용량을 1 일 1 회, 8 일간 경구 투여한 $\mathrm{GR} 6 \mathrm{~F} 4$ 투여군, 총 4 그룹으로 분류하였으며, 각 군에 6마리씩 배정하였다. 실험 9일 째, 절식을 24시간 한 후, LPS $20 \mathrm{mg} / \mathrm{kg}$ 을 복강주사하고 24시 간 후 ethyl ether로 가볍게 흡입 마취하여, 심장에서 혈액을 채 취하였고 즉시 원심분리기를 이용해 혈청을 분리하였다. 그 후 에, saline $(0.9 \% \mathrm{NaCl}, \mathrm{pH} 7.4)$ 관류하여 장기를 채취해 무게 를 측정한 후, 분석 전까지 $-80^{\circ} \mathrm{C}$ 로 급속 냉동하여 보관하였다.

실험동물의 체중은 전자체중계로 1 회/ 1 일으로 동일 시간 동 일 조건에서 측정하였고, 실험종료일 체중에서 실험 개시 전 체 중을 빼서 체중 증가량(body weight gain $(\mathrm{g})$ )을 산출하였다. 식 이섭취량은 8 일동안 제공된 사료에서 8 일간 섭취하고 남은 사 료량을 제한 후 각 실험군의 하루 평균 식이섭취량을 산출하였 다. 한편, 각 쥐의 체중증가량을 동일 사육기간의 사료섭취량으 로 나누어 식이효율(FER: food efficiency ratio)을 구하였다.

\section{혈청의 ALT, AST 측정}

심장에서 채취한 혈액을 원심분리기에 $4,000 \mathrm{rpm}$ 으로 10 분간 원 심분리하여 혈청을 얻었다. 혈청 중 aspartate aminotransferase (AST), alanine amino-transferase (ALT) 활성도는 ReitmanFrankel법에 의해 제조된 시약 키트를 사용하여 $505 \mathrm{~nm}$ 에서 UV spectrophotometer로 비색정량하여 측정하였고, 혈청 liter당 international unit (IU/L)으로 나타내었다.

\section{ROS 측정}

심장에서 채혈한 혈액을 $4,000 \mathrm{rpm}$ 로 10 분간 원심분리하여 혈 청을 얻었고 간 조직은 $1 \mathrm{mM}$ EDTA-50 mM sodium phosphate buffer (pH 7.4)를 이용하여 분쇄하였다. 혈청 내의 ROS를 측 정하기 위하여 $25 \mathrm{mM} \mathrm{DCFH-DA를} \mathrm{혼합한} \mathrm{후,} \mathrm{형광} \mathrm{광도계를}$ 이용하여 0 분부터 매 10 분씩 emission wavelength of $530 \mathrm{~nm}$ 와 ex-citation wavelength of $485 \mathrm{~nm}$ 를 이용하여 30 분간 측정 한 산출 값을 계산하였다.

\section{Western Blot Analysis}

간의 세포질단백질을 얻기 위해 $100 \mathrm{mM}$ Tris- $\mathrm{HCl}(\mathrm{pH} 7.4)$,

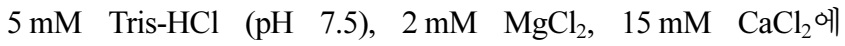
$1.5 \mathrm{M}$ sucrose, $0.1 \mathrm{M}$ DTT protease inhibitor cocktail을 첨가 한 buffer $\mathrm{A}$ 를 넣고 tissue grinder로 분쇄한 후 $10 \% \mathrm{NP}-40$ 용액을 첨가하였다. 아이스 위에서 20 분간 정치시킨 후 12,000 $\mathrm{rpm}$ 으로 2 분간 원심분리 하여 세포질단백질을 포함하고 있는 상층액을 분리하였다. 핵단백질을 얻기 위해 $10 \% \mathrm{NP}-40$ 가 더 해진 buffer $\mathrm{A}$ 에 두 번 헹구고 $100 \mu \mathrm{L}$ 의 buffer C $(50 \mathrm{mM}$ HEPES, $50 \mathrm{mM} \mathrm{KCl}, 0.3 \mathrm{mM} \mathrm{NaCl}, 0.1 \mathrm{mM}$ EDTA, $1 \mathrm{mM}$ DTT, $0.1 \mathrm{mM}$ PMSF, $10 \%$ glycerol)를 첨가해 재부유 시킨 뒤 10 분마다 vortex를 3 번 하였다. $4^{\circ} \mathrm{C}$ 에서 $12,000 \mathrm{rpm}$ 으로 10 분간 원심 분리한 후 핵단백질을 포함하고 있는 상층액을 얻어 -80 ${ }^{\circ} \mathrm{C}$ 에서 각각 냉동 보관하였다. 간 조직의 세포질단백질의 $\mathrm{iNOS}$, $\mathrm{COX}-2, \mathrm{TNF}-\alpha, \beta$-actin 및 핵단백질 AP-1, NF- $\mathrm{kB}$ p65, Histone의 발현을 측정하기 위해 $10 \mu \mathrm{g}$ 의 단백질을 $8-15 \%$ SDS-polyacrylamide gel을 이용하여 전기영동 후, acrylamide gel을 nitrocellulose membrane으로 이동시켰다. 준비된 membrane 
에 각각의 1 차 antibody를 처리하여 $4^{\circ} \mathrm{C}$ 에서 overnight 시킨 다 음 PBST로 6분마다 5회 세척하고, 각각 처리된 1차 항체에 사 용되는 2차 항체(PBST로 1:3000로 희석해서 사용)를 사용하여 상온에서 1시간 반응시킨 후, PBST로 6 분마다 5회 세척하였다. 그리고 ECL 용액에 노출시킨 후, Sensi-Q2000 Chemidoc (Lugen Sci Co., Ltd., Seoul, Korea)에 감광시켜 단백질 발현 을 확인한 후, 해당 band를 ATTO Densitograph Software (ATTO Corporation, Tokyo, Japan)프로그램을 사용하여 정량하 였다.

\section{조직학적 분석}

실험 종료 후, 간 조직을 적출한 다음, $10 \%$ 중성 포르말린에 18 시간 이상 고정시킨 다음, 탈수를 거쳐 파라핀 포매 후 $4 \mu \mathrm{m}$ 의 절편을 제작하였다. 이후 Hematoxylin \& eosin (H\&E) 염 색을 실시하고, 광학 현미경 하에서 200배 확대하여 관찰하였다.

\section{통계처리}

모든 수치는 평균 \pm 표준오차(Mean $\pm \mathrm{SEM}$ 로 표시하였으며, SPSS (22.0 for Windows program)를 사용하여 one-way analysis of variance (ANOVA)로 유의수준 $p$-value $<0.05$ 에서 검정하였다.

\section{결 과}

\section{DPPH radical scavenging activity}

$\mathrm{GR} 0 \mathrm{~F} 0$ 는 $\mathrm{DPPH}$ radical scavenging activity가 $20.04 \pm 0.61 \%$ 로 나타나는 반면, GR6F4는 $60.57 \pm 0.90 \%(p<0.001)$ 로 3 배가 넘는 항산화 효과를 나타내었다. GR9F0는 $52.45 \pm 0.74 \%(p<0.001)$ 로
두 번째로 높은 DPPH radical scavenging activity를 나타내었 다(Table 1).

\section{ABTS radical scavenging activity}

$\mathrm{GR} 0 \mathrm{~F} 0$ 는 $39.84 \pm 0.60 \%$ 의 ABTS radical scavenging activity를 나타내어 가장 높은 항산화 활성을 보였고, GR6F4가 $32.77 \pm 0.73 \%$ $(p<0.001)$ 로 두 번째로 높은 활성을 나타내었다(Table 2).

\section{성분분석}

Gastrodin의 retention time (RT)는 23.053분이었고, gastrodigenin 의 RT는 24.979분으로 나타났다(Fig. 1). 면적비를 이용한 검량 선은 gastrodin, gastrodigenin 모두 $\mathrm{R}^{2}=0.9999$ 로 양호한 직진성 을 나타내었다(Fig. 2).

발효 천마의 gastrodin, gastrodigenin의 함량을 분석하여 다음 과 같이 나타내었다. tr은 검출은 되지만 정량값이 의미가 없는 것을 의미한다. gastrodin의 경우 GR6F0가 $1289.52 \pm 98.49 \mu \mathrm{g} /$ $\mathrm{mL}$ 로 가장 많았고, $\mathrm{GR} 9 \mathrm{~F} 0$ 가 다음으로 많았다. $\mathrm{GR} 6 \mathrm{~F} 4$ 의 gastrodigenin 함량이 $1698.84 \pm 18.08 \mu \mathrm{g} / \mathrm{mL}$ 로 GR0F0의 798.98 $\pm 19.14 \mu \mathrm{g} / \mathrm{mL}$ 에 비해 높은 함량을 보였다(Table 3).

\section{최종 시료 선정}

천마는 GR6F4의 gastrodigenin 함량이 $1698.84 \pm 18.08 \mu \mathrm{g} / \mathrm{mL}$ 로 $\mathrm{GR} 0 \mathrm{~F} 0$ 의 $798.98 \pm 19.14 \mu \mathrm{g} / \mathrm{mL}$ 에 비해 높은 함량을 보였다. 또 한 DPPH scavenging activity에서도 GR6F4가 $60.57 \pm 0.90 \%$ 로 가장 우수한 효과를 보였으며, ABTS scavenging activity에서 역시 $32.77 \pm 0.73 \%$ 로 2 번째로 우수한 효과를 보였다. 따라서 본 연구자는 $\mathrm{GR} 0 \mathrm{~F} 0$ 와 $\mathrm{GR} 6 \mathrm{~F} 4$ 간의 효능 평가가 가능할 것으 로 사료되어, 최종 시료로 선정하였다.

Table 1 DPPH Radical Scavenging Activity of Gastrodiae Rhizoma and Processed Gastrodiae Rhizoma

\begin{tabular}{|c|c|c|c|c|c|}
\hline & F0 & F1 & F2 & F3 & F4 \\
\hline$\overline{\text { GR0 }}$ & $20.04 \pm 0.61 \%$ & $24.87 \pm 0.22 \% * * *$ & $16.17 \pm 0.93 \%$ & $23.34 \pm 0.56 \%$ & $20.45 \pm 0.89 \%$ \\
\hline GR1 & $20.29 \pm 0.35 \%$ & $22.72 \pm 0.74 \%^{* *}$ & $18.21 \pm 0.50 \%$ & $20.23 \pm 0.35 \% * * *$ & $17.24 \pm 1.73 \%$ \\
\hline GR3 & $35.99 \pm 1.33 \% * * *$ & $33.06 \pm 0.61 \%$ & $26.95 \pm 1.52 \% *$ & $30.13 \pm 0.61 \%$ & $23.81 \pm 1.09 \% * * *$ \\
\hline GR6 & $46.52 \pm 0.92 \% * * *$ & $41.07 \pm 0.77 \% * * *$ & $43.17 \pm 0.69 \% * * *$ & $39.57 \pm 0.82 \% * * *$ & $60.57 \pm 0.90 \% * * *$ \\
\hline GR9 & $52.45 \pm 0.74 \% * * *$ & $41.45 \pm 0.36 \% * * *$ & $34.67 \pm 1.19 \% * * *$ & $44.64 \pm 0.58 \% * * *$ & $48.55 \pm 1.02 \% * * *$ \\
\hline
\end{tabular}

GR0: Dried Gastrodiae rhizoma without steaming. GR1: Gastrodiae rhizoma with 1 time processing $\dagger$, GR3: Gastrodiae rhizoma with 3 time processing $\dagger$, GR6: Gastrodiae rhizoma with 6 time processing $\dagger$, GR9: Gastrodiae rhizoma with 9 time processing $\dagger$. F0: not fermented, F1: Lactobacillus plantarum, F2: Leuconostoc mesenteroides, F3: Streptococcus thermophilus, F4: Saccharomyces cerevisiae

$\dagger$ Drying after steaming for four hours at $90^{\circ} \mathrm{C}$

${ }^{*} p<0.05,{ }^{* *} p<0.01$ and ${ }^{* * *} p<0.001$ significantly different from the GR0F0

Table 2 ABTS radical scavenging activity of gastrodiae rhizoma and Fermented gastrodiae rhizoma

\begin{tabular}{cllll}
\hline & \multicolumn{1}{c}{ F0 } & \multicolumn{1}{c}{ F1 } & F2 & F3 \\
\hline GR0 & $39.84 \pm 0.60 \%$ & $17.68 \pm 0.42 \%$ & $20.89 \pm 1.17 \%$ & $16.38 \pm 0.16 \%$ \\
GR1 & $23.02 \pm 0.40 \%$ & $20.28 \pm 0.51 \%$ & $21.57 \pm 1.39 \%$ & $19.83 \pm 0.56 \% * * *$ \\
GR3 & $28.62 \pm 0.05 \%$ & $20.12 \pm 1.06 \%$ & $21.33 \pm 0.09 \%$ & $20.03 \pm 0.50 \%$ \\
GR6 & $27.42 \pm 0.39 \% * * *$ & $25.38 \pm 1.20 \% * * *$ & $28.18 \pm 0.44 \% * * *$ & $23.01 \pm 0.68 \% * * *$ \\
GR9 & $28.11 \pm 0.42 \%$ & $21.93 \pm 0.66 \% * * *$ & $24.98 \pm 0.51 \% *$ & $20.30 \pm 0.24 \% * * *$ \\
\hline
\end{tabular}

GR0: Dried Gastrodiae rhizoma without steaming. GR1: Gastrodiae rhizoma with 1 time processing†, GR3: Gastrodiae rhizoma with 3 time processing†, GR6: Gastrodiae rhizoma with 6 time processing†, GR9: Gastrodiae rhizoma with 9 time processing $\dagger$. F0: not fermented, F1: Lactobacillus plantarum, F2: Leuconostoc mesenteroides, F3: Streptococcus thermophilus, F4: Saccharomyces cerevisiae

$\dagger$ Drying after steaming for four hours at $90^{\circ} \mathrm{C}$

${ }^{*} p<0.05, * * p<0.01$ and $* * * p<0.001$ significantly different from the GR0F0 


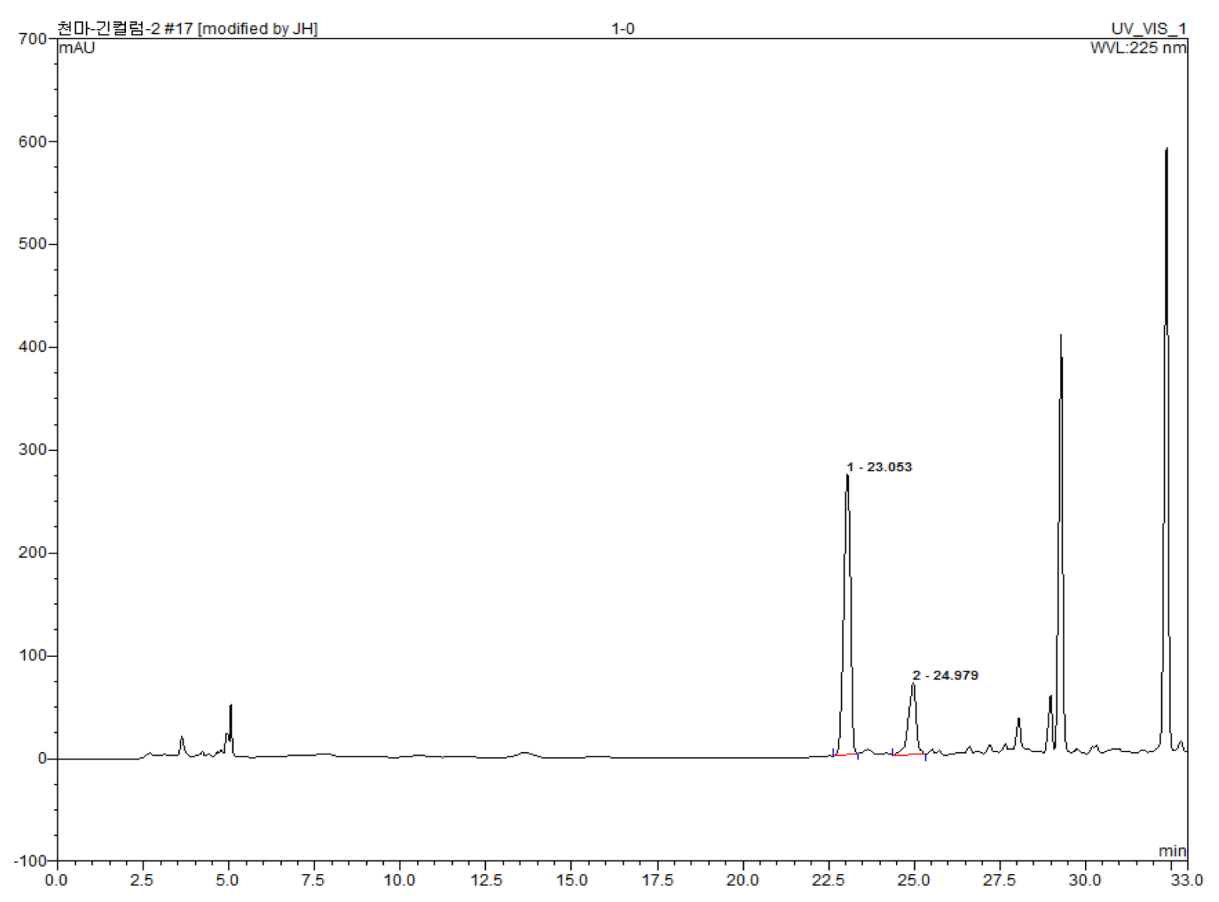

Fig. 1 HPLC Chromatogram of Gastrodin and Gastrodigenin
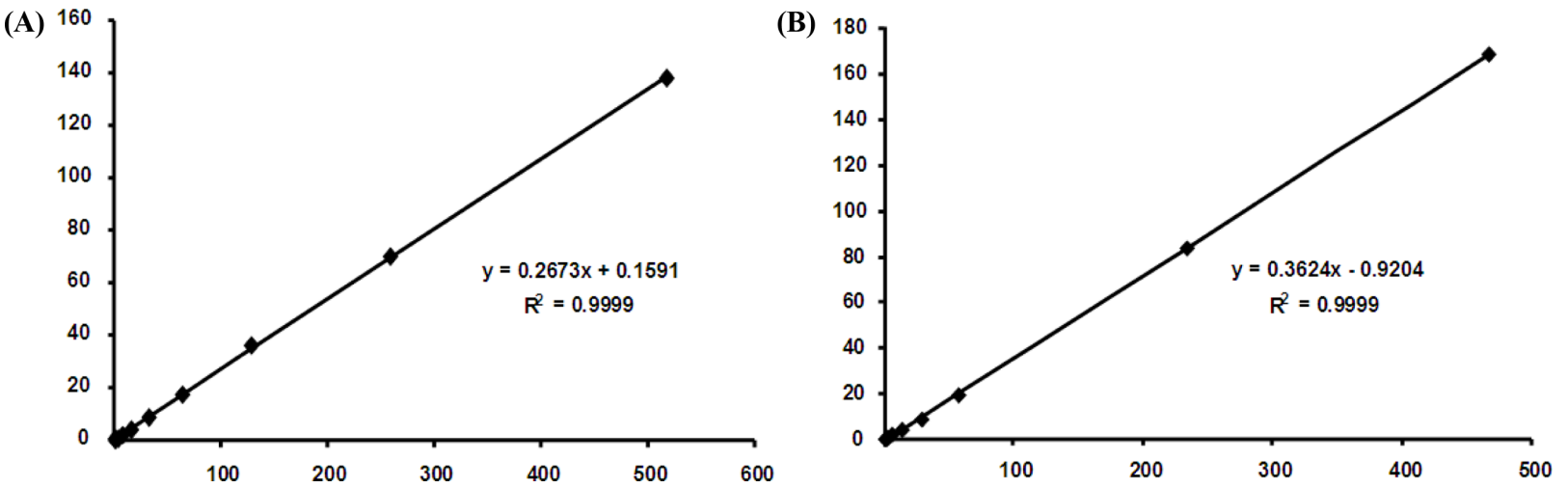

Fig. 2 Calbration Curve of Components of Gastrodiae Rhizoma: (A): gastrodin, (B): gastrodigenin

\section{LPS에 의한 급성 간손상 개선효능평가}

적응기간을 제외한 식이 급여기간 8 일 동안 측정된 체중변화 및 식이효율은 시간에 따라 체중이 일정하게 증가하는 것으로 나타났다(Table 4).

실험 종료 후, 실험동물의 체중에 대한 간 조직의 질량비에 서 대조군 $(79.57 \pm 2.80 \mathrm{mg} / \mathrm{g}(p<0.001))$ 에 비하여 정상군 $(56.06$

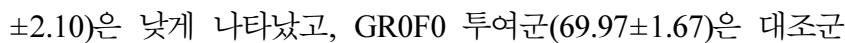
에 비하여 감소하였으며, GR6F4 투여군(67.12 $\pm 3.05 \quad(p<0.05))$ 은 대조군에 비하여 유의성 있게 감소하는 것으로 나타났다(Fig. $3)$.

혈청의 ALT, AST 평가

간 조직의 손상은 세포 내부에 존재하는 효소가 혈액으로 유출 되는 것을 측정함으로써 확인해 볼 수 있는데, 혈청 중 ALT와 $\mathrm{AST}$ 의 상승은 간 손상으로 인한 간세포의 파괴가 진행되면서
아미노기 전이효소가 혈중으로 나와 높게 나타나는 것이므로 간 세포의 파괴 및 변성의 지표가 될 수 있다(Gabriel 등, 1982). $\mathrm{ALT}$ 는 정상군 $(2.61 \pm 1.50 \mathrm{IU} / \mathrm{L})$ 에 비하여 대조군 $(16.05 \pm 2.55$ $(p<0.001))$ 은 간세포의 파괴로 인하여 유의성 있게 증가되었고,

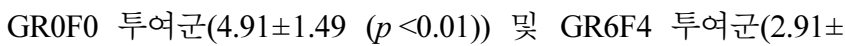
$3.01(p<0.001))$ 은 대조군에 비해 유의성 있게 발현이 적게 나 타났다.

AST는 정상군 $(26.00 \pm 1.28 \mathrm{IU} / \mathrm{L})$ 에 비하여 대조군 $(68.85 \pm 2.98$ $(p<0.001))$ 은 유의성 있게 증가하였으며, GR0F0 투여군(33.34 $\pm 5.25)$ 은 대조군에 비해 적게 발현했으나 유의성은 없었고, GR6F4 투여군 $(31.74 \pm 5.28 \quad(p<0.001))$ 은 유의성 있게 발현이 적게 나타났다(Fig. 4).

\section{$\mathrm{ROS}$ 측정}

$\mathrm{ROS}$ 는 혈청에서 정상군 $(29.80 \pm 2.68$ fluorescence $/ \mathrm{min} / \mathrm{mL})$ 에 비 
Table 3 Composition of Gastrodiae Rhizoma and processed Gastrodiae Rhizoma

\begin{tabular}{|c|c|c|}
\hline Items & Gastrodin $(\mu \mathrm{g} / \mathrm{mL})$ & Gastrodigenin $(\mu \mathrm{g} / \mathrm{mL})$ \\
\hline GR0F0 & $3.60 \pm 0.28$ & $798.98 \pm 19.14$ \\
\hline GR0F1 & $\operatorname{tr}$ & $513.04 \pm 5.81$ \\
\hline GR0F2 & $\operatorname{tr}$ & $528.41 \pm 6.24$ \\
\hline GR0F3 & $\operatorname{tr}$ & $561.02 \pm 4.55$ \\
\hline GR0F4 & $\operatorname{tr}$ & $621.77 \pm 12.32$ \\
\hline GR1F0 & $463.88 \pm 2.37$ & $106.55 \pm 1.05$ \\
\hline GR1F1 & $\operatorname{tr}$ & $1093.98 \pm 6.88$ \\
\hline GR1F2 & $\operatorname{tr}$ & $1144.12 \pm 0.43$ \\
\hline GR1F3 & $\operatorname{tr}$ & $1069.12 \pm 9.73$ \\
\hline GR1F4 & $\operatorname{tr}$ & $1053.98 \pm 15.98$ \\
\hline GR3F0 & $826.05 \pm 9.51$ & $24.93 \pm 3.61$ \\
\hline GR3F1 & $\operatorname{tr}$ & $1080.77 \pm 15.91$ \\
\hline GR3F2 & $\operatorname{tr}$ & $1100.44 \pm 4.21$ \\
\hline GR3F3 & $\operatorname{tr}$ & $1014.94 \pm 21.80$ \\
\hline GR3F4 & $\operatorname{tr}$ & $1082.27 \pm 5.98$ \\
\hline GR6F0 & $1289.52 \pm 98.49$ & $13.37 \pm 3.04$ \\
\hline GR6F1 & $\operatorname{tr}$ & $807.35 \pm 6.56$ \\
\hline GR6F2 & $\operatorname{tr}$ & $1152.48 \pm 4.45$ \\
\hline GR6F3 & $\operatorname{tr}$ & $832.43 \pm 7.74$ \\
\hline GR6F4 & $\operatorname{tr}$ & $1698.84 \pm 18.08$ \\
\hline GR9F0 & $1278.42 \pm 6.59$ & $53.36 \pm 4.48$ \\
\hline GR9F1 & $\operatorname{tr}$ & $584.43 \pm 7.21$ \\
\hline GR9F2 & $\operatorname{tr}$ & $820.75 \pm 3.93$ \\
\hline GR9F3 & $\operatorname{tr}$ & $859.88 \pm 6.45$ \\
\hline GR9F4 & $\operatorname{tr}$ & $1267.63 \pm 7.18$ \\
\hline
\end{tabular}

GR0: Dried Gastrodiae rhizoma without steaming. GR1: Gastrodiae rhizoma with 1 time processing*, GR3: Gastrodiae rhizoma with 3 time processing*, GR6: Gastrodiae rhizoma with 6 time processing*, GR9: Gastrodiae rhizoma with 9 time processing*. F0: not fermented, F1: Lactobacillus plantarum, F2: Leuconostoc mesenteroides, F3: Streptococcus thermophilus, F4: Saccharomyces cerevisiae. *Drying after steaming for four hours at $90^{\circ} \mathrm{C}$

하여 대조군 $(43.56 \pm 1.87 \quad(p<0.01))$ 은 높게 나타났고, GR0F0 투 여군(35.87 \pm 2.37$)$ 은 대조군에 비하여 적게 발현하였으나, 유의 성은 없었고 $\mathrm{GR} 6 \mathrm{~F} 4$ 투여군 $(34.03 \pm 3.13(p<0.01))$ 은 대조군에 비하여 유의성 있게 적은 발현을 보였다(Fig. 5A).

조직에서의 ROS는 정상군 $(31.92 \pm 1.95$ fluorescence $/ \mathrm{min} / \mathrm{mg}$ protein)에 비하여 대조군(47.25 $\pm 4.39 \quad(p<0.01))$ 은 증가하였고, GR0F0 투여군(28.62 $\pm 1.01 \quad(p<0.001))$ 과 GR6F4 투여군(27.99 $\pm 1.03(p<0.001))$ 은 대조군에 비하여 유의성 있게 발현이 적게 나타났다(Fig. 5B).

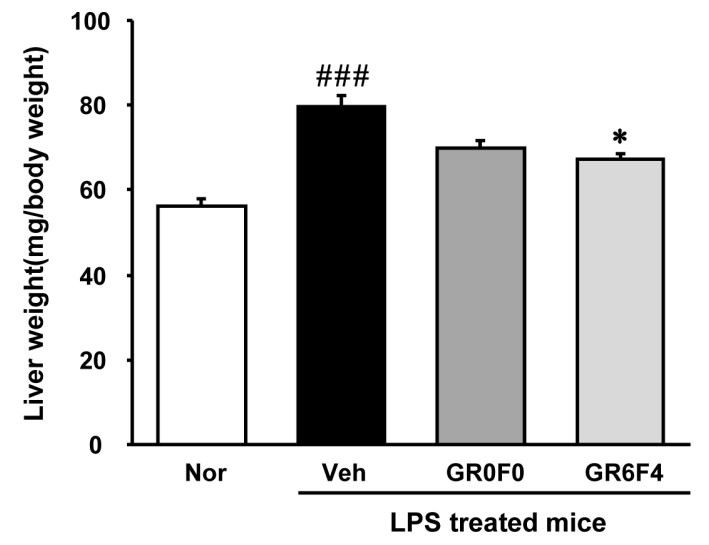

Fig. 3 Liver Weight of LPS-treated Mice. Nor: normal mice, Veh: LPS treated mice, GR0F0: Fed GR0F0 $200 \mathrm{mg} / \mathrm{kg}$ following LPS-treated mice, GR6F4: Fed GR6F4 $200 \mathrm{mg} / \mathrm{kg}$ following LPS-treated mice. All data are expressed mean $\pm \mathrm{SEM}, \mathrm{n}=6$ mice per group. Vehicle group significance was compared to normal treated LPS group $(\# p<0.001)$ Sample group significance was compared to vehicle treated LPS group $\left({ }^{*} p<0.05\right)$

\section{간 조직의 염중성 사이토카인 및 매개인자 측정}

$\mathrm{NF}-\kappa \mathrm{B}$ 는 염증에 관여하는 유전자의 발현을 조절하는 전사인자 로 cytokine에 의해 세포 표면 수용체가 자극됨으로써 발현이 시작된다. NF- $\kappa \mathrm{B}$ 는 세포 증식을 조절하는 표적 유전자의 발현 을 증가시키고, 항균 물질의 방출을 촉진하고 면역 반응을 촉 진시킨다(Hayden과 Ghosh 2008). 또 다른 전사인자인 AP-1은 c-Jun, c-Fos로 구성되어 있으며, 이들은 각각 $\mathrm{SAPK} / \mathrm{JNK}$ 와 extracellular single-regulated kinase $1 / 2$ 의 영향을 받는다(Abe 등, 1996). NF- $\kappa \mathrm{B}$ 와 AP-1은 TNF- $\alpha$, IL- $1 \beta$, IL-6 gene의 transactivation에 필요한 전사인자로 작용하며 $\mathrm{iNOS}, \mathrm{COX}-2$ 와 같은 염증성 매개물의 발현을 증가시킨다(Baud 등, 2009). iNOS와 $\mathrm{COX}-2$ 에 의해 생성된 $\mathrm{NO}$ 와 $\mathrm{PGE}$ 는 염증반응을 증가시키는 강 력한 물질이다(Vane 등, 1994).

간 조직에서 western blot을 실시하여 염증성 매개인자인 AP1 과 NF- $\kappa \mathrm{B}$ p65를 측정하였다. 그 결과 $\mathrm{AP}-1$ 의 발현은 정상군 $(1.00 \pm 0.11)$ 에 비하여 대조군 $(1.68 \pm 0.15(p<0.001))$ 은 유의성 있 게 높게 나타났고, GR0F0 투여군 $(1.11 \pm 0.24 \quad(p<0.05))$ 및 $\mathrm{GR} 6 \mathrm{~F} 4$ 투여군 $(0.96 \pm 0.12(p<0.01))$ 은 대조군에 비해 유의성 있 게 적게 나타났다(Fig, 6A).

$\mathrm{NF}-\kappa \mathrm{B}$ p65의 발현은 대조군 $(1.87 \pm 0.09(p<0.001))$ 은 정상군 $(1.00 \pm 0.14)$ 에 비해 유의성 있게 증가하였고, GR0F0 투여군 $(1.78 \pm 0.15)$ 및 $\mathrm{GR} 0 \mathrm{~F} 4$ 투여군 $(1.70 \pm 0.16)$ 에서는 대조군에 비하

Table 4 Initial and Final Body Weights, Body Weight Changes, and Body Weight Reduction Ratios in ICR Mice

\begin{tabular}{ccccc}
\hline Group & Initial body weight $(\mathrm{g})$ & Final body weight $(\mathrm{g})$ & Body weight gain $(\mathrm{g})$ & FER $(\%)$ \\
\hline Nor & $33.02 \pm 0.54$ & $35.56 \pm 0.77$ & $2.54 \pm 0.33$ & 0.16 \\
Veh & $32.52 \pm 0.37$ & $34.50 \pm 0.41$ & $2.07 \pm 0.14$ & 0.14 \\
GR0F0 & $31.59 \pm 0.32$ & $33.65 \pm 0.35$ & $2.06 \pm 0.30$ & 0.15 \\
GR6F4 & $31.60 \pm 0.57$ & $33.96 \pm 0.52$ & $2.36 \pm 0.25$ & 0.16 \\
\hline
\end{tabular}

Nor: normal mice, Veh: LPS treated mice, GR0F0: Fed GR0F0 $200 \mathrm{mg} / \mathrm{kg}$ following LPS-treated mice, GR6F4: Fed GR6F4 $200 \mathrm{mg} / \mathrm{kg}$ following LPS-treated mice. All data are expressed mean $\pm \mathrm{SEM}, \mathrm{n}=6$ mice per group. Significance: ${ }^{*} p<0.05,{ }^{* *} p<0.01,{ }^{* * *} p<0.001$ vs. LPS treated mice 
(A)

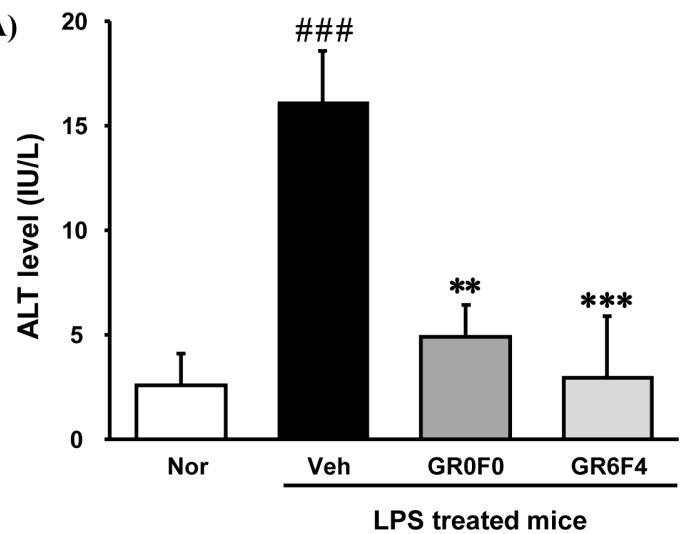

(B)

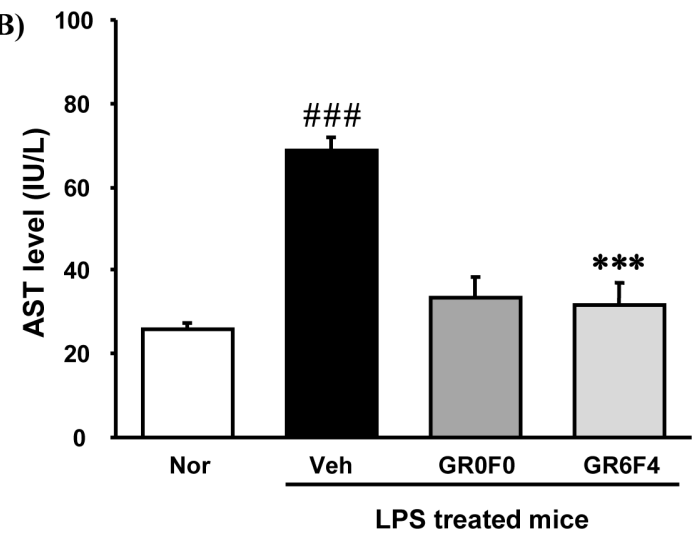

Fig. 4 Evaluation of Alanine Aminotransferase (ALT) and Aspartate Amino-transferase (AST) in LPS-treated Mice. Nor: normal mice, Veh: LPS treated mice, GR0F0: Fed GR0F0 $200 \mathrm{mg} / \mathrm{kg}$ following LPS-treated mice, GR6F4: Fed GR6F4 $200 \mathrm{mg} / \mathrm{kg}$ following LPS-treated mice. All data are expressed mean $\pm \mathrm{SEM}, \mathrm{n}=6$ mice per group. Vehicle group significance was compared to normal treated LPS group $\left({ }^{\# \#} p<0.001\right)$ Sample group significance was compared to vehicle treated LPS group $\left(* * p<0.01,{ }^{* * *} p<0.001\right)$

(A)
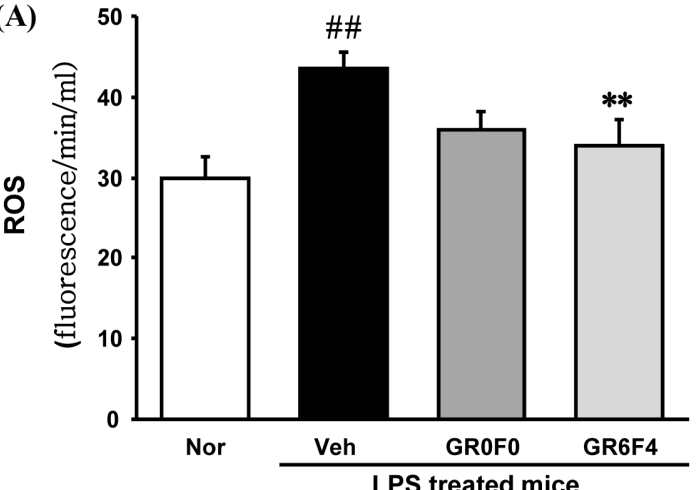

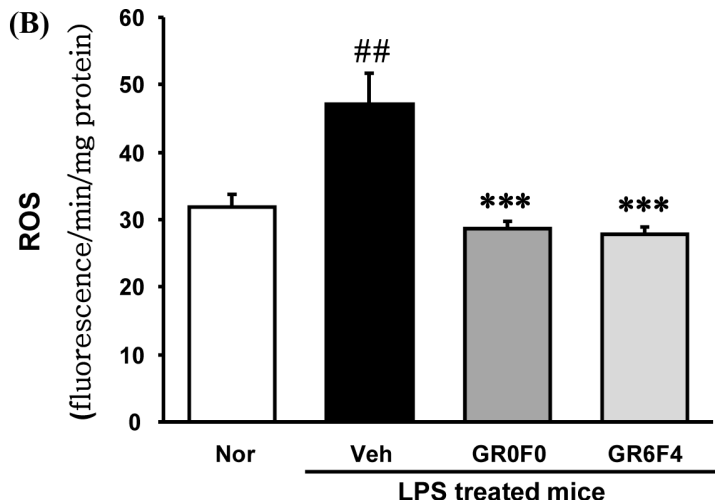

Fig. 5 Reactive Oxygen Species (ROS) in Serum and Liver Tissues. (A) ROS in serum, (B) ROS in liver tissues. Nor: normal mice, Veh: LPS treated mice, GR0F0: Fed GR0F0 200 mg/kg following LPS-treated mice, GR6F4: Fed GR6F4 $200 \mathrm{mg} / \mathrm{kg}$ following LPS-treated mice. All data are expressed mean \pm SEM, $n=6$ mice per group. Vehicle group significance was compared to normal treated LPS group $(\# p<0.01)$. Sample group significance was compared to vehicle treated LPS group $\left({ }^{* *} p<0.01,{ }^{* * *} p<0.001\right)$

여 적게 나타나는 경향은 있었으나 유의성은 없었다(Fig. 6B).

염증반응에서 중요한 역할을 하는 염증 매개체인 $\mathrm{PGE}$ 와 $\mathrm{NO}$ 는 각각 $\mathrm{COX}$ 와NOS에 의해 생성된다. $\mathrm{COX}$ 는 2 가지 형태 $(\mathrm{COX}-$ $1, \mathrm{COX}-2$ )가 존재하며, 이 중 $\mathrm{COX}-2$ 의 발현은 성장인자, 사이 토카인 등의 자극에 의해 유도된다(Crofford 1997). 한편 NOS 에는 3 가지 형태(neuronal NOS, inducible NOS, endothelial $\mathrm{NOS}$ )가 존재하며, 이들 중 $\mathrm{iNOS}$ 가 염증 반응에서 중요한 역 할을 차지한다(Nathan 1992). COX-2, iNOS와 TNF- $\alpha$ 의 발현 을 확인한 결과, 대조군에서의 $\mathrm{COX}-2(1.85 \pm 0.32(p<0.01))$ 는 정상군 $(1.00 \pm 0.03)$ 에 비하여 크게 증가하였고, GR0F0 투여군 $(1.23 \pm 0.13(p<0.05))$ 및 $\mathrm{GR} 6 \mathrm{~F} 4$ 투여군 $(1.01 \pm 0.06 \quad(p<0.01))$ 에서 대조군에 비하여 유의성 있게 적은 발현이 나타났다(Fig. 7A).

$\mathrm{iNOS}$ 의 발현은 정상군 $(1.00 \pm 0.08)$ 에 비하여 대조군 $(1.68 \pm 0.26$ $(p<0.01))$ 은 유의성 있게 증가하였고, GR0F0 투여군 $(1.23 \pm 0.12$ $(p<0.05))$ 및 $\mathrm{GR} 6 \mathrm{~F} 4$ 투여군 $(0.92 \pm 0.05 \quad(p<0.01))$ 의 경우 대조 군에 비하여 유의성 있게 발현이 적게 나타났다(Fig. 7B).
$\mathrm{TNF}-\alpha$ 는 대표적인 inflammatory cytokine으로 내피세포에서 ICAM-1, ALCAM-1, VCAM-1과 같은 부착분자들의 생산을 촉 진하여 각종 백혈구들을 염증부위로 이동시키는 역할을 한다 (Briscoe 등, 1992) (Gamber 1985). TNF- $\alpha$ 의 발현은 정상군 $(1.00 \pm 0.08)$ 에 비하여 대조군 $(1.46 \pm 0.17 \quad(p<0.01))$ 은 유의성 있 게 증가하였고, 대조군에 비해 GR0F0 투여군 $(1.20 \pm 0.08)$ 은 적 게 발현했으나, 유의성이 없었고 GR6F4 투여군 $(1.13 \pm 0.05$ $(p<0.05))$ 에서는 대조군에 비해 유의성 있게 감소하였다(Fig. 7C).

\section{조직학적 분석}

정상군(A)에 비하여 대조군(B)에서는 혈관주위의 염증정도가 증 가하였으며, 핵이 현저하게 줄어든 모습을 관찰할 수 있으며, $\mathrm{GR0F0}$ 투여군(C)과 GR6F4 투여군(D)에서는 대조군에 비하여 혈관주위의 염증 정도가 약하고 핵의 유무가 뚜렷하게 구분되 는 모습을 관찰할 수 있었다(Fig. 8). 
(A)
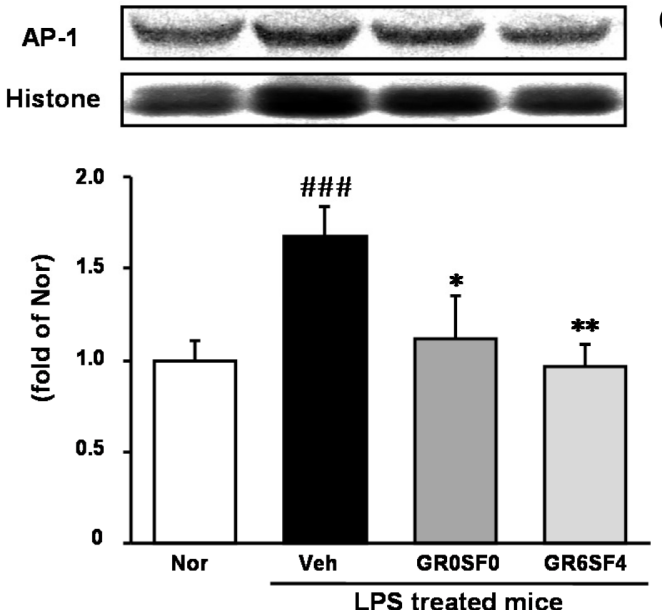

(B)

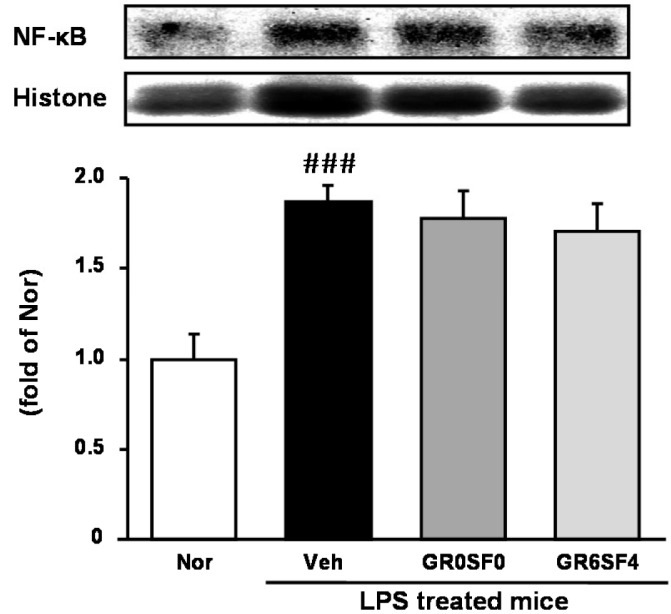

Fig. 6 Expression of Inflammation-related Proteins in Liver. Inflammtion-related proteins AP-1: (A), nuclear factor-kappa B (NF- $\kappa$ B): (B) Nor: normal mice, Veh: LPS treated mice, GR0F0: Fed GR0F0 $200 \mathrm{mg} / \mathrm{kg}$ following LPS-treated mice, GR6F4: Fed GR6F4 200 mg/kg following LPS-treated mice. All data are expressed mean \pm SEM, $n=6$ mice per group. Vehicle group significance was compared to normal treated LPS group (\#\# $p<0.001$ ) Sample group significance was compared to vehicle treated LPS group $\left({ }^{*} p<0.05, * * p<0.01\right)$
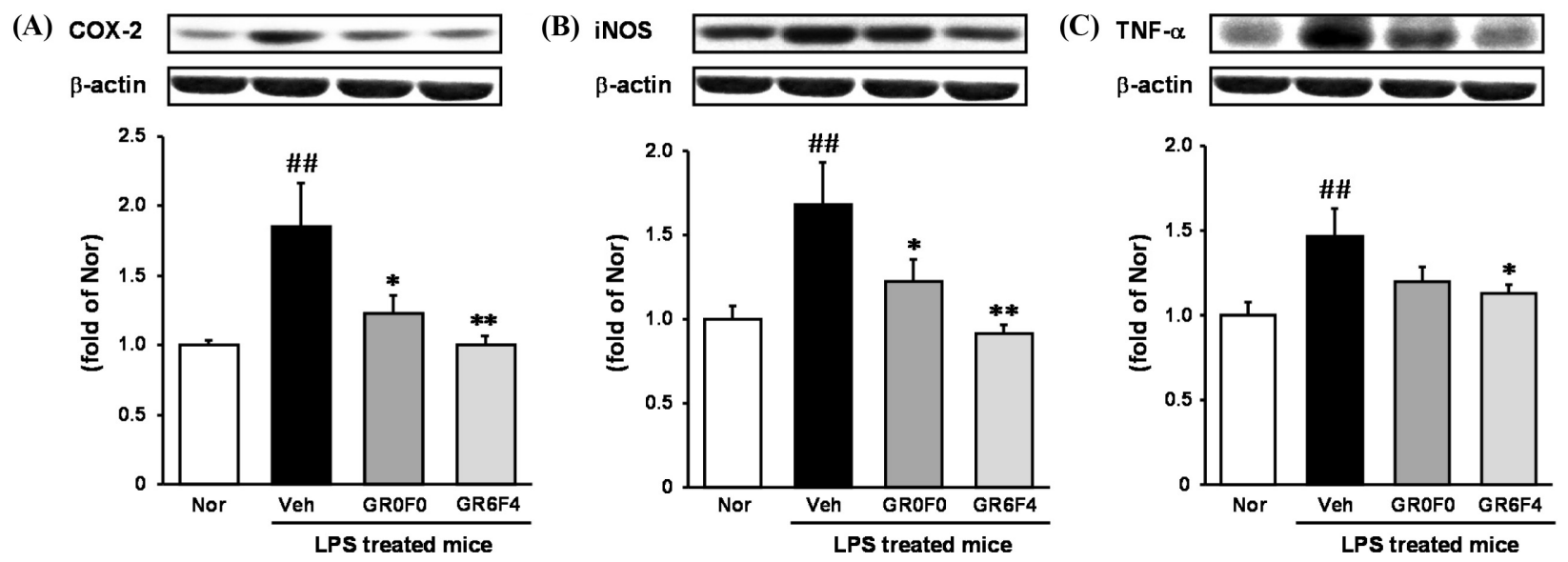

Fig. 7 Expression of Inflammation-related Proteins in Liver.. Inflammtion-related proteins cyclooxygenase-2 (COX-2): (A), induciblenitric oxide synthase (iNOS): (B), Tumor necrosis factor $\alpha$ (TNF $\alpha$ ): (C). Nor: normal mice, Veh: LPS treated mice, GR0F0: Fed GR0F0 200 mg/kg following LPS-treated mice, GR6F4: Fed GR6F4 $200 \mathrm{mg} / \mathrm{kg}$ following LPS-treated mice. All data are expressed mean \pm SEM, n=6 mice per group. Vehicle group significance was compared to normal treated LPS group $\left({ }^{\#} p<0.01\right)$ Sample group significance was compared to vehicle treated LPS group $\left({ }^{*} p<0.05,{ }^{* *} p<0.01\right)$

\section{고 찰}

본 연구에서는 발효한 천마와 기존 천마와의 비교를 통해 발효 천마의 유의성을 알아보기 위하여 성분 분석, 항산화 활성 및 동물 실험을 수행하였다.

천마를 증숙한 후, Lactobacillus plantarum, Leuconostoc mesenteroides, Streptococcus thermophilus, Saccharomyces cerevisiae 4가지 균주를 사용하여 액상 발효한 25 가지 시료의 항산화 효능과 유효성분의 함량을 알아보았다.

$\mathrm{DPPH}$ radical scavenging activity의 경우 증숙의 횟수가 증 가할수록 더 많은 활성산소 소거능을 보였으나, ABTS radical scavenging activity의 경우는 천마를 발효했을 때 라디칼 소거 능이 감소하는 경향을 보였다. DPPH radical scavenging activity 에서는 가장 높은 활성도를 보인 시료는 GR6F4였다. ABTS radical scavenging activity의 경우 GR0F0가 가장 높은 활성도 를 보였고, GR6F4가 다음으로 높은 활성도를 보였다. 이는 $\mathrm{Heo}$ 등(2006)의 연구와 일치하게 천마가 뛰어난 항산화 효능을 가지는 결과를 나타내었고, 또한 증숙 및 발효가 ABTS radical 소거능을 유의하게 증가시키는 결과를 확인 할 수 있었다.

천마의 증숙과 발효 따른 유효성분의 함량을 살펴본 결과 천 마는 6증까지 증숙 횟수가 증가할수록 gastrodin은 증가하고, gastrodigenin은 감소하는 경향을 보였다. 이는 증숙이 gastrodin 의 분해를 방지한다는 기존의 발표에 합치된다. 또한 발효한 천 마 모두에서 gastrodin이 거의 검출되지 않은 것을 보아 천마의 gastrodin이 발효균주에 의해 gastrodigenin으로 전환된 것으로 사료된다.

천마와 증숙발효 천마의 성분 함량은 gastrodin의 경우 $\mathrm{GR} 6 \mathrm{~F} 0$ 에서 $1289.52 \pm 98.49 \mu \mathrm{g} / \mathrm{mL}$ 로 가장 많았고, gastrodigenin 
(A)

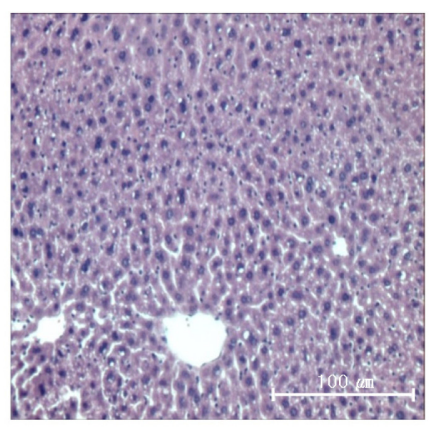

(C)

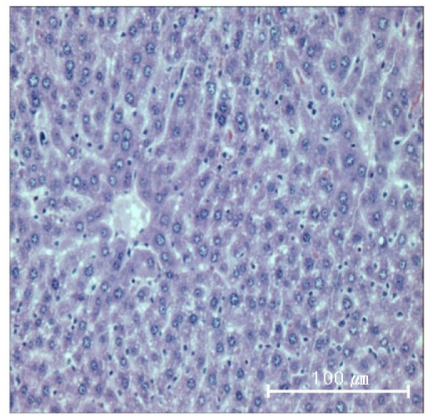

(B)

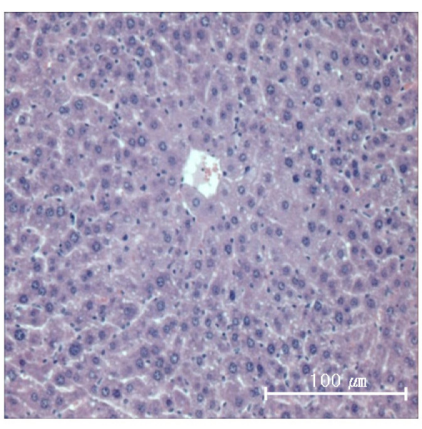

(D)

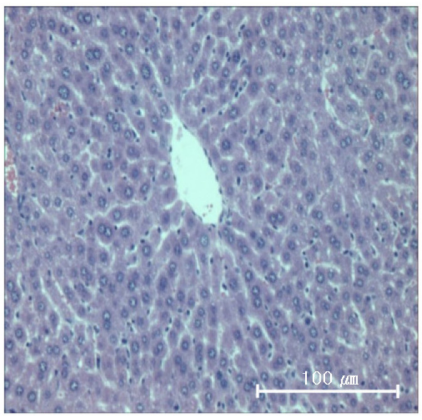

Fig. 8 Effect of GR0F0, GR6F4 on The Histopathological Change Liver Tissues of LPS-treated Mice. Liver tissues were stained with H\&E (Original magnification $\times 200$ ). (A) Normal mice, (B) Vehicle treated LPS mice, (C) Fed GR0F0 $200 \mathrm{mg} / \mathrm{kg}$ following LPS-treated mice, (D) Fed GR6 F4 $200 \mathrm{mg} / \mathrm{kg}$ following LPS-treated mice

은 GR6F4에서 $1698.84 \pm 18.08 \mu \mathrm{g} / \mathrm{mL}$ 로 가장 많았다.

위의 결과로 많은 유효성분을 함유하고 높은 항산화 활성을 보인 6회 증숙 후 4번 미생물(S. cerevisiae)로 발효시킨 GR6F4 가 생건 천마인 $\mathrm{GR} 0 \mathrm{~F} 0$ 와 함께 최종 시료로 선정하게 되었다.

최종 선정된 시료를 LPS를 이용한 급성 간손상 개선 효능평 가 모델에 적용하여 간 기능 개선 효능을 평가하였다. ICR mice에 먼저 8일간 경구로 $\mathrm{GR} 0 \mathrm{~F} 0$ 와 $\mathrm{GR} 6 \mathrm{~F} 4$ 를 투여하였다. 경 구 투여 기간 동안의 체중변화 및 식이효율을 살펴본 결과, 실 험군 모두 시간에 따른 체중이 일정하게 증가하여 GR0F0나 $\mathrm{GR6F4}$ 에 의한 독성은 없는 것으로 판단되었다.

혈청의 $\mathrm{ALT}, \mathrm{AST}$ 활성도를 검사한 결과, 혈청 $\mathrm{ALT}$ 의 경우 대조군에 비해 GR0F0 투여군, GR6F4 투여군 모두 적게 발현 되었다. 특히, GR6F4 투여군에서는 ALT 수치가 정상군과 비 슷한 정도로 감소하였다.

혈청 AST의 경우 GR0F0 투여군은 대조군에 비해 적게 발 현되었으나 유의성은 없었고, GR6F4 투여군에서는 유의성 있 게 적은 발현을 보였다. 이를 통해 천마 및 증숙발효 천마의 간 기능 개선 효과를 확인할 수 있었다.

산화적 스트레스 바이오마커인 ROS를 혈청에서 측정한 결과, GR0F0 투여군은 대조군에 비해 적게 나타났으나 유의성은 없 었고, GR6F4 투여군에서는 유의성 있게 적게 발현되었다. 간 조직에서의 ROS는 GR0F0 투여군과 GR6F4 투여군에서 대조 군에 비해 모두 유의성 있게 적게 발현하였다.

간 조직에서 Western blot을 실시하여 AP-1을 측정한 결과, $\mathrm{AP}-1$ 의 발현은 대조군에 비해 GR0F0 투여군과 GR6F4 투여군 에서 모두 유의성 있게 감소하였으며 특히 GR6F4 투여군에서
는 정상군과 비슷한 수준의 $\mathrm{AP}-1$ 이 측정되었다.

반면, NF-kB p65의 발현에서는 대조군에 비해 GR0F0 투여 군, GR6F4 투여군 모두 유의성 있는 감소를 보이지 않았다. 이 로 보아 천마의 항염증의 기전이 전사인자 $\mathrm{AP}-1$ 의 발현에 관 여하는 것으로 생각된다.

$\mathrm{COX}-2$ 와 iNOS에서는 GR0F0 투여군 및 GR6F4 투여군이 대조군에 비하여 적게 발현되었다. 특히 GR6F4 투여군에서는 정상군 수준의 COX-2, iNOS의 발현을 보였다.

TNF- $\alpha$ 발현의 경우, GR6F4 투여군에서만 대조군에 비해 유 의성 있는 감소를 보였고 GR0F0 투여군은 TNF- $\alpha$ 의 발현 대 조군에 비하여 감소하였으나 유의성은 없었다. 이를 통해 천마 와 발효 증숙발효천마는 전사인자 $\mathrm{AP}-1$ 의 신호전달체계를 억제 함으로써 iNOS, COX-2와 TNF- $\alpha$ 의 발현이 적게 나타나는 것 으로 판단할 수 있었다.

실험종료 후, 간 조직을 적출한 후, 광학 현미경 하에서 각 각의 조직을 살펴본 결과, 대조군에 비해 $\mathrm{GROF0}$ 투여군과 GR6F4 투여군에서 혈관주위의 염증이 적게 발견되었고, 핵이 뚜렷하게 구분되는 것을 확인할 수 있었다.

이상의 결과로 볼 때 LPS에 의해 유발된 간세포손상에서 천 마와 증숙발효 천마 투여군 모두에서 항산화 효과를 확인할 수 있었다. 천마와 증숙발효 천마는 LPS로 생성되는 산화인자를 억제하여 간세포 손상을 예방하는 것으로 사료되며 천마에 비 하여 증숙발효 천마가 보다 양호한 효과를 보이는 것으로 생각 된다. 이는 향후 천마의 발효에 대한 충분한 연구와 함께 기존 천마의 효능에 따른 발효 천마의 연구 또한 필요할 것으로 사 료된다. 


\section{초 록}

본 연구의 목적은 증숙 및 발효과정을 거친 천마추출물이 LPS 로 유도된 간 손상에 미치는 효능을 평가하고자 하였다. 증숙 횟수 및 발효균을 달리한 25 가지 시료 중 $\mathrm{DPPH}$ 와 $\mathrm{ABTS}$ 라 디칼 소거능을 측정하여 생 천마 $(\mathrm{GR} 0 \mathrm{~F} 0)$ 와 6회 증숙한 후, Saccharomyces cerevisiae균으로 발효한 GR6F4간의 비교실험이 가능할 것으로 사료되었다. 마우스는 6마리씩 4그룹(정상군, 대 조군, GR0F0 투여군, GR6F4투여군)으로 나누어 실험을 진행하 였다. LPS를 투여하기 전, 각 시료를 $200 \mathrm{mg} / \mathrm{kg} / \mathrm{day}$ 로 8 일간 경구 투여하였으며, 간 손상을 유발하기 위하여 LPS를 $20 \mathrm{mg}$ $\mathrm{kg}$ 로 복강투여하였다. 혈액에서 AST, ALT를 측정한 결과, 대 조군에서 그 수치가 증가하였고, GR6F4군에서 감소하였을 뿐 아니라, 혈액 및 간에서 측정한 $\mathrm{ROS}$ 수치 또한 유의하게 감소 하였다. 간조직에서 $\mathrm{AP}-1, \mathrm{COX}-2, \mathrm{TNF}-\alpha$ 와 INOS를 측정한 결과, GR0F0 또한 감소하였으나, 증숙 및 발효과정을 거친 $\mathrm{GR} 6 \mathrm{~F} 4$ 군에서 더욱 큰 효과를 보이는 것을 확인하였다. 이러한 결과들은 GR6F4의 뛰어난 항산화 및 항염증 효과를 증명하며, 그러므로 증숙 및 발효과정을 거친 천마는 간 손상에 보호효과 가 있다고 보여진다.

Keywords 간손상 - 발효 - 천마 - 항산화 - 항염증 · Lipopolysaccharide

\section{References}

Abe J, Kusubara M, Ulevitch RJ, Berk BC, Lee JD (1996) Big mitogenactivated protein kinase 1 (BMK1) is a redox-sensitive kinase. $\mathrm{J}$ boil Chem 271: 16586-16590

Baud V, Karin M (2009) Is NF-кB a good target for cancer therapy? Hopes and pitfalls. Nat Rev Drug Discov 8: 33-40

Briscoe DM, Cotran RS, Pober JS (1992) Effect of tumor necrosis factor, lipopolysaccharide, and IL-4 on the expression of vascular cell adhesion molecule-1 in vivo: correlation with CD3+ T cell infiltration. J Immunol 149: $2594-2960$
Choi JH (2012) The Study on Chemical Analysis and Increased Physiological Activities of Fermented Gastrodia Extracts (Gastrodia elata var. Blume). Dissertation, Yeungnam University

Choi SR, Jang I, Kim CS, You DH, Kim JY, Kim YG, Ahn YS, Kim JM, Kim YS, Seo KW (2011) Changes of Components and Quality in Gastrodiae Rhizoma by Different Dry Methods. Korean J Medicinal Crop Sci 19: $354-361$

Crofford LJ (1997) COX-1 and COX-2 tissue expression: implications and prediction. J Rheumatol Suppl 49: 15-19

Gabriel LP, William R, Hewitt (1982) Principles and Methods of toxicology. Raven Press. San Diego

Gamber JR, Harlan JM, Klebanoff SJ, Vadas MA (1985) Stimulation of the adherence of neutrophils to umbilical vein endothelium by human recombinant tumor necrosis factor. Proc Natl Acad Sci USA 82: 85678571

Hayden MS, Ghosh S (2008) Shared principles in NF-kB signaling. Cell 132: 344-362

Heo JC, Park JY, An SM, Lee JM, Yun CY, Shin HM, Kwon TK, Lee SH (2006) Anti-oxidant and Anti-tumor Activities of Crude extracts by Gatrodia elasta Blume. Korean J Food Preserv 13: 83-87

Kim GY, Song HJ (2002) Hanyak pojehak. Shinilbooks. Seoul

Kim JM, Moon YS, Yoon KY, Suh SG (2010) Quality Properties and Preference of Fermented Gastrodia elata Blume. Kor J Hort Sci Technol 28: $507-514$

Ko CH (2010) Characterization of unique proteins from fresh and fermented Gastrodia elata. Dissertation, Yeungnam University

Kwon SU (2012) Anti-diabetic Effect of Fermented Gastrodia elata blume on STZ-induced Type 1 Diabetic Mice. Dissertation, Wonkwang University

Lee KH, Rhee KH, Kim BS, Choi YH, Kim CH (2013) Sleep Inducing Effect of Gastrodia elata Fermented with Lactic Acid Bacteria. Kor J Pharmacogn 44: 281-285

Nathan C (1992) Nitric oxide as a secretory product of mammalian cells. FASEB J 6: 3051-3064

Sin MG (2008) Clinical Traditional Herbalogy. Yeongrimsa, Seoul

Song MH, Bae JT, Ko HJ, Jang YM, Lee JD, Lee GS, Pyo HB (2011) AntiOxidant Effect and Anti-Inflammatory of Fermented Citrus unshiu Peel Extract by using Schizophyllum commune. J Soc Cosmet Scientists Korea 37: 351-356

Vane JR, Mitchell JA, Appleton I, Tomlinson A, Bishop-bailey D, Croxtall J, Willoughby DA (1994) Inducible isoforms of cyclooxygenase and nitricoxide synthase in inflammation. National Acad Sciences 91: 2046-2050 